\title{
LARP1 paper combined elife 7-2-20
}

Shelly C. $\mathrm{Lu}^{1}$

${ }^{1}$ Affiliation not available

July 6, 2020

\section{Hosted file}

LARP1 paper combined elife 7-2-20.pdf available at articles/465547-larp1-paper-combined-elife-7-2-20

https://authorea.com/users/339300/ 